\title{
KUALITAS PELAYANAN KHUSUS PEREMPUAN DAN ANAK YANG BERHADAPAN DENGAN HUKUM DI SUBDIT IV RENAKTA DITRESKRIMUM POLDA KALTENG PROVINSI KALIMANTAN TENGAH TAHUN 2020
}

\author{
Quality of Special Services for Women and Clildren in Conflict with the Law in Sub- \\ Directorate IV Renakta Ditreskrimum Polda Central \\ Kalteng Province Kalimantan in 2020
}

\section{Milka ${ }^{\text {** }}$ \\ Maya $^{2}$ \\ Mita Sari ${ }^{3}$}

I Universitas Muhammadiyah Palangka Raya Provinsi Kalimantan Tengah Indonseia

2 Kota Palangka Raya Provinsi Kalimantan Tengah Indonseia

3 Kota Palangka Raya Provinsi Kalimantan Tengah Indonseia

*email: milkaniez22@gmail.com

Kata Kunci:

I. Kualitas Pelayanan

2. Perempuan dan Anak yang Berhadapan Dengan Hukum

Keywords:

I. Quality of Service

2. Women and Children Dealing with the Law

\begin{abstract}
Abstrak
Penelitian ini bertujuan untuk menganalisis kualitas pelayanan perempuan dan anak yang berhadapan dengan hukum di Subdit IV Renakta Ditreskrimum Polda Kalteng. Peneliti menggunakan desain penelitian deskritif kualitatif yang bertujuan untuk menggambarkan kualitas pelayanan. Informan penelitian ini pelapor, korban dan petugas di Subdit IV/Renakta Ditreskrimum Polda Kalteng. Penelitian ini dilakukan di Subdit IV Renakta Ditreskrimum Polda Kalteng dengan tehnik pengumpulan data melalui wawancara terstruktur, observasi dan dokumentasi.

Hasil penelitian kualitas pelayanan di ruang pelayanan khusus perempuan dan anak yang berhadapan dengan hukum di Subdit IV Renakta Ditrekrimum Polda Kalteng belum optimal dari segi inovasi keterbukaan informasi eksternal seperti instagram maupun facebook dan jangka waktu penyelesaian perkara yang cukup lama. Adapun faktor penghambat dari kualitas pelayanan ruang pelayanan khusus perempuan dan anak yang berhadapan dengan hukum di Subdit IV Renakta Ditrekrimum Polda Kalteng adalah: I) keterbukaan informasi eksternal, 2) jangka waktu penyelesaian perkara.

Saran penelitian, perlunya Subdit IV Renakta Ditreskrimum Polda Kalteng melakukan inovasi terkait dengan keterbukaan informasi publik dalam pembuatan laporan dan akses perkembangan perkara untuk mempermudah masyarakat mendapatkan informasi terkait laporan yang telah dibuat dan penyampaian kepada masyarakat terkait jangka waktu penyelesain perkara hingga selesai.
\end{abstract}

\begin{abstract}
This study aims to analyze the quality services of special service room for women and children dealing with the law in Subdit IV Renakta Ditreskrimum Polda Kalteng. This study used a qualitative descriptive research design that aims to describe the quality of service. that are reporters, victims and officers at Subdit IV / Renakta Ditreskrimum Polda Kalteng. This research was conducted in Subdit IV Renakta Ditreskrimum Polda Kalteng. Researchers conducted structured interviews, observation and documentation to obtain research data.

The results of this research can be concluded that the quality of service rooms for women and children in Subdit IV Renakta Ditreskrimum Polda Kalteng not optimal in terms of innovation of public information disclosure such as Instagram, Facebook, and the period of time for completing cases also. The inhibiting factors of quality service room specifically for women and children who are dealing with the law in Subdit IV Renakta Ditrekrimum Polda Kalteng are: I) external information disclosure, 2) the period of time for completing cases.

Suggestions for this research, Subdit IV Renakta Ditreskrimum Polda Kalteng need to make innovations related to the openness of public information in making reports and access to case progress to make it easier for the public to get information related to reports that have been made and convey to the public regarding the time period for completing the case to completion.
\end{abstract}




\section{PENDAHULUAN}

Kekerasan terhadap perempuan setiap tahunnya semakin meningkat, berdasarkan data dari Komnas Perempuan pada tahun 2018 jumlah kasus yang dilaporkan sebesar 348.466 dan meningkat sebesar 14 \% pada tahun 2019 yaitu menjadi 406.178. Berdasarkan data-data yang terkumpul tersebut jenis kekerasan terhadap perempuan yang paling menonjol sama seperti tahun sebelumnya adalah KDRT (Kekerasan Dalam Rumah Tangga/RP (ranah personal) yang mencapai angka $71 \%$ (9.637) dengan rincian sebagai berikut kekerasan fisik 3.927 kasus (4I\%), menempati peringkat pertama disusul kekerasan seksual sebanyak 2.988 kasus (3l\%), psikis 1.658 (17\%) dan ekonomi I.064 kasus (1I\%), dan pada tahun 2020 jumlah kekerasan terhadap perempuan sebanyak 299.91। kasus.

Sedangkan jumlah kekerasan terhadap anak di Indonesia berdasarkan riset dan pendataan Komisi Perlindungan Anak Indonesia (KPAl) tahun 2018 mengatakan bahwa jumlah laporan anak yang berhadapan dengan hukum baik yang menjadi korban atau pelaku sebanyak 10.186 orang, jumlah ini di data dari tahun 201I hingga tahun 2018 dengan jumlah anak yang berhadapan dengan hukum setiap tahun nya meningkat sekitar $10 \%$ pada tahun 2019 dengan jumlah kasus sebanyak I.019 kasus dan pada tahun 2020 periode Januari 2020 hingga Juni 2020 sebanyak 3.087 kasus.

Sedangkan di Kalimantan Tengah, berdasarkan data dari Subdit IV Ditreskrimum Polda Kalteng, jumlah kekerasan terhadap perempuan dan anak pada tahun 2018 sebesar 57 kasus dengan korban anak sebanyak 37 orang dan korban perempuan sebanyak 20 orang. Kemudian data pada tahun 2019, jumlah kekerasan terhadap perempuan dana anak mengalami peningkatan yaitu sejumlah 103 kasus, dengan korban perempuan sebanyak 35 orang dan korban anak sebanyak 68 orang. Pada tahun 2020 terdapat 58 kasus kekerasan terhadap perempuan dan anak dengan korban perempuan sebanyak 17 orang dan korban anak sebanyak 30 orang. Kekerasan yang dialami perempuan dan anak tersebut di dominasi terhadap kekerasan fisik dan seksual, pada tahun 2018 kekerasan fisik sebesar $44 \%$ dan kekerasan seksual sebesar $56 \%$. Pada tahun 2019 kekerasan fisik yang dialami perempuan dan anak sebesar $33 \%$ dan kekerasan seksual sebesar 66\%, kemudian pada tahun 2020 kekerasan fisik yang dialami perempuan dan anak sebesar $28 \%$ dan kekerasan seksual sebesar $66 \%$.

Banyaknya jumlah perempuan dan anak yang berhadapan dengan hukum tentunya membutuhkan pelayanan khusus dikarenakan perempuan dan anak yang sedang bermasalah dengan hukum mempunyai kondisi psikis yang tertekan dan kecemasan yang tinggi. Berdasarkan pengamatan peneliti di Subdit IV Renakta Ditreskrimum Polda Kalteng terhadap perempuan dan anak yang berhadapan dengan hukum, mereka terlihat cemas dan bingung terkait permasalahan yang dialaminya. Oleh karena itu diperlukannya Pelayanan yang cepat, tepat dan nyaman terhadap para korban dan hal ini sangat ditentukan oleh sumber daya manusia, fasilitas, saranan dan prasarana pelayanan.

Menurut Moenir (2015 : 192) bahwa pelayanan publik adalah kegiatan yang dilakukan oleh seseorang atau sekelompok orang dengan landasan faktor material melalui sistem, prosedur, dan metode tertentu dalam usaha memenuhi kepentingan orang lain sesuai dengan haknya. Kegiatan pelayanan publik yang diselenggarakan oleh pemerintah kepada masyarakat meliputi banyak hal yang menyangkut semua kebutuhan masyarakat. Pada prinsipnya pelayanan publik senantiasa selalu ditingkatkan kinerjanya sesuai dengan keinginan masyarakat 
pengguna jasa. Standar Pelayanan Publik menurut Keputusan Menteri Pemberdaya Aparatur Negara nomor 63/KEP/M.PAN/7/20I3, sekurang- kurangnya meliputi: I) Prosedur Pelayanan, 2) Waktu Pelayanan, 3) Biaya Pelayanan, 4) Produk Pelayanan, 5) Sarana dan Prasarana, 6) Komponen Petugas Pelayanan. Untuk mengukur apakah pelayanan tersebut berkualitas maka menurut Parasuraman, dkk (Mulyawan: 2016) terdapat 5 dimensi untuk mengukur kualitas pelayanan yakni: I) Tangiabel, 2) Reiability, 3) Responsiveness, 4) Assurance, 5) Emphaty.

Guna membangun pelayanan yang berkualitas khususnya terhadap perempuan dan anak, maka pada tahun 2007 dalam organisasi Polri telah dibentuk unit PPA (Perlindungan Perempuan dan Anak) dengan maksud untuk memberikan pelayanan yang lebih baik dalam bentuk perlindungan terhadap korban kejahatan dan penegakan hukum kepada pelaku, yang diatur dalam perkap No. Pol 10 tahun 2007 dan diwajibkannya pembentukan RPK (Ruang Pelayanan Khusus) yang tertuang dalam Pasal 5 Perkap No. Pol. 3 tahun 2008, fasilitas tersebut dibuat untuk memberikan pelayanan dan perlindungan khusus kepada perempuan dan anak yang menjadi saksi, korban dan/atau tersangka yang ditangani di RPK.

Pembentukan Ruang RPK di Subdit IV Renakta Ditreskrimum Polda Kalteng baru terlaksana pada tahun 2018, hal ini dikarenakan Polda Kalteng masih menunggu giliran untuk pembangunan RPK yang telah dijadwalkan oleh Mabes Polri.

Pada penelitian sebelumnya yang dilaksanakan di Subdit IV Renakta Ditreskrimum Polda Kalteng oleh Jati, AT et al tahun 2017 yang menyatakan bahwa sarana dan prasarana unit PPA Ditreskrimum polda kalteng juga belum maksimal karena belum adanya RPK, sehingga masih ada keluhan dari masyarakat yang dimana seperti kurangnya fasilitas Televisi, dan Wifi.
Masyarakat merasa jenuh saat menunggu giliran pemeriksaan oleh penyidik terutama korban atau saksi anak yang cenderung cepat bosan. Oleh karena itu Peneliti merasa perlunya di lakukan penelitian terkait Kualitas Pelayanan Ruang Pelayanan Khusus Perempuan dan Anak yang berhadapan dengan hukum di Subdit IV Renakta Ditreskrimum Polda Kalteng.

\section{METODE PENELITIAN}

Peneliti mengunakan desain penelitian deskritif kualitatif yang bertujuan untuk menggambarkan kualitas pelayanan. Dengan tehnik pengumpulan data melalui wawancara terstruktur, observasi dan dokumentasi.

\section{HASIL DAN PEMBAHASAN}

Berdasarkan hasil penelitian yang dilakukan oleh peneliti dengan menggunakan teknik wawancara, observasi dan dokumentasi, yang kemudian peneliti menganalisis hasil tersebut dengan menggunakan teori Parasuraman, (Mulyawan: 2016) yaitu berupa indikator: Terwujud (Tangibles), Kehandalan (Reliability), Ketanggapan (Responsiveness), Jaminan (Assurance), dan Empaty (Emphaty) sebagai berikut:

I. Indikator Tangiable berupa terwujud dan adanya penampakan fisik yang memadai yang berkaitan dengan teori kualitas pelayanan publik Pasuraman, (Mulyawan: 2016), maka ruang Subdit IV Renakta dari segi fisik sudah memenuhi poin dari indikator Tangiable. Hal ini sesuai Pasal 6 Peraturan Kapolri Nomor 3 Tahun 2008 menerangkan bahwa fasilitas dan perlengkapan RPK meliputi: ruang tamu, ruang konseling, ruang kontrol/ pemeriksaan, dan ruang istirahat yang dilengkapi TV, penyejuk ruangan, alat tulis dan kelengkapan lainnya yang diperlukan. Namun dari segi inovasi keterbukaan informasi eksternal masih belum 
optimal karena masih ada keluhan masyarakat terkait belum tersedianya prosedur atau persyaratan dalam pembuatan laporan atau pengaduan yang tertuang di media sosial seperti facebook dan instagram.

2. Indikator Kehandalan di ruang Subdit IV/ Renakta sudah baik. Berdasarkan Observasi, Peneliti pada saat melakukan pengamatan di Ruang Subdit IV Renakta, setiap petugas terlihat teliti dalam mempersiapkan dokumen pembuatan laporan ataupun sebelum melakukan pemeriksaan terhadap korban dengan menyipakan pertanyaan terlebih dahulu sesuai dengan pasal yangdilaporkan oleh pihak pelapor atau korban, selain itu juga para petugas sudah terbiasa menggunakan media seperti komputer dan printer dalam melaksanakan pelayanan.

3. Indikator Daya Tanggap (Responsiveness) di Ruang Subdit IV Renakta sudah bagus namun belum optimal di jangka waktu penyelesaian perkara. Hal ini dapat dilihat dari pelayanan yang diberikan petugas diruang Subdit IV Renakta, nampak bahwa petugas cukup cepat, cermat dan teliti dalam memberikan pelayanan serta mendengarkan setiap keluhan atau masalah yang disampaikan oleh korban atau pelapor. Petugas yang memberikan pelayanan terhadap perempuan dan anak adalah petugas Polwan sehingga korban anak ataupun perempuan lebih terbuka dalam menyampaikan masalahnya. Belum optimalnya jangka waktu penyelesaian perkara tersebut diatas dibenarkan oleh petugas yang menangani perkara, hal ini dikarenakan petugas harus mengikuti prosedur sesuai dengan manajemen penyidikan sebagaimana diatur dalam Peraturan Kapolri Nomor 6 Tahun 2019 tentang penyidkan tindak pidana. Berdasarkan Peraturan Kapolri No. 6 tahun 2019 tentang Penyidikan Tindak Pidana, Pasal I4 ayat (I), Penyidik harus mengirimkan Surat Pemberitahuan Dimulainya Penyidikan (SPDP) kepada Jaksa Penuntut Umum (JPU) dan tersangka dalam waktu 7 hari terhitung saat surat perintah penyidikan terbit. Kemudian dalam Pasal I4 ayat (5) Penyidik menyerahkan berkas perkara ke JPU dalam waktu 30 hari dan apabila berkas perkara belum dapat dikirimkan maka penyidik wajib memberitahukan kepada JPU perkembangan perkaranya denga melampirkan SPDP. Berikutnya JPU meneliti berkas perkara yang diserahkan oleh penyidik dalam waktu I4 hari untuk menetukan apakah berkas perkara sudah lengkap (P2I) atau belum lengkap (PI9), apabila berkas belum lengkap maka penyidik wajib melengkapi berkas tersebut dan segera mengirimkan kembali kepada JPU dalam waktu paling lambat I4 hari. Selanjutnya JPU membuat tuntutan dan dakwaan terhadap pelaku tindak pidana yang kemudian diserahkan ke Pengadilan dan kemudian pelapor dan para saksi serta terlapor dihadirkan ke persidangan.

4. Indikator ke empat yaitu Jaminan (Assurance) yang diberikan oleh ruang pelayanan khusus (RPK) Subdit IV/ Renakta sudah optimal dan sesuai dengan harapan pelapor maupun korban, petugas memberikan pelayanan sesuai dengan jam kerja dari pukul 07.00 wib - 14.00 wib, selain itu petugas juga dibantu oleh petugas yang melaksanakan piket dan standby selama I x 24 jam dalam memberikan pelayanan kepada masyarakat, sehingga mempermudah masyarakat dalam membuat laporan ataupun pengaduan. Petugas juga menerangkan bahwa dalam pembuatan laporan ataupun proses penyelesaian perkara tidak dipungut biaya. Pelayanan yang tidak dipungut biaya tentunya sangat membantu bagi masyarakat, 
khususnya masyarakat yang tidak mampu namun ingin mendapat keadilan dengan melaporkan permasalahannya ke Kepolisian. Hal ini sesuai dengan buku standar pelayanan Direktorat Reserse Kriminal Umum yang mengacu pada Peraturan Menteri Pendayagunaan Aparatur Negara dan Reformasi Birokrasi Nomor 15 Tahun 2014 tentang Pedoman Standar Pelayanan, bahwa setiap pelayanan yang diberikan tidak dipungut biaya.

5. Indikator ke lima yaitu Empati (Emphaty) yang diberikan oleh petugas di ruang pelayanan khusus (RPK) Subdit IV Renakta sudah bagus dan optimal, hal ini dapat dilihat dari hasil observasi peneliti saat melakukan pengamatan di ruang Subdit Renakta, petugas yang melayani pembuatan laporan yang berkaitan dengan anak dan perempuan adalah petugas Polwan. Petugas juga bersikap ramah, sopan dan santun terhadap pelapor atau korban yang datang dengan menanyakan terlebih dahulu permasalahan pelapor sebelum dibuatnya laporan, petugas juga menjelaskan alur dari proses hukum yang akan berjalan sehingga masyarakat yang membuat laporan mengetahui proses selanjutnya yang akan dihadapi setelah membuat laporan.

\section{Faktor-faktor penghambat Kualitas Pelayanan} Khusus Perempuan dan Anak Yang Berhadapan Dengan Hukum di Subdit IVI Renakta Ditreskrimum Polda Kalteng

I. Keterbukaan informasi eksternal

Faktor penghambat kualitas pelayanan di ruang pelayanan khusus Subdit IV Renakta adalah dari segi inovasi keterbukaan informasi eksternal, dimana masih terdapat keluhan dari korban ataupun pelapor yang menyampaikan bahwa persyaratan dan prosedur pembuatan laporan masih belum di informasikan diruang publik seperti media sosial instagram ataupun facebook yang saat ini banyak digunakan oleh masyarakat, sehingga masyarakat yang membuat laporan dapat menyiapkan administrasi dan persyaratan apa saja yang diperlukan sebelum membuat laporan dan datang ke Ditreskrimum Polda Kalteng serta tidak bolakbalik mengambil persyaratan tersebut kerumah. Keterbukaan informasi eksternal sangat diperlukan, di era internet saat ini banyak masyarakat yang menggunakan media sosial untuk mencari informasi, hal ini di dukung oleh Tjiptono (2011:185) yang menyampaiakn bahwa salah satu faktor pendukung maupun penghambat kualitas pelayanan adalah faktor komunikasi eksternal. Komunikasi eksternal merupakan bentuk komunikasi yang diarahkan kepada pelanggan, yakni edukasi pelanggan, manajemen ekspektasi/ harapan pelanggan dan pembentukakn citra positif perusahaan. Edukasi pelanggan merupakan cara perusahaan dalam mendidik pelanggan misalnya mengajarkan pelanggan cara mengisi formulir pelayanan, mengikuti alur pembayaran sesuai dengan prosedur dan sebagainya.

2. Jangka waktu penyelesaian perkara Faktor penghambat kualitas pelayanan ruang pelayanan khusus di Subdit IV Renakta adalah jangka waktu penyelesaian perkara, dimana masih terdapat pelapor atau korban yang mengeluhkan lama nya waktu penyelesaian perkara hingga ke persidangan membutuhkan waktu yang berbulan-bulan. Hal ini memang dibenarkan oleh petugas yang menangani perkara karena petugas melakukan penyelidikan dan penyidikan berdasaran aturan sebagaimana di muat dalam Peraturan Kapolri Nomor 6 Tahun 2019 tentang penyidikan tindak pidana sehingga 
penyidik atau petugas harus teliti dan cermat dalam menetukan laporan yang di laporkan oleh masyarakat adalah suatu tindak pidana atau bukan dan untuk menetukan tersangka serta pembuktian juga memerlukan waktu yang cukup panjang. Selain itu untuk menyelesaikan perkara, petugas juga tidak bekerja sendiri, namun harus koordinasi dengan Jaksa Penuntut Umum (JPU) hingga nanti berkas perkara dianggap sudah lengkap (P2I) oleh JPU yang kemudian di sidangkan di Pengadilan.

Perihal tersebut diatas sesuai dengan teori yang disampaikan Moenir (2014) bahwa salah satu faktor yang mempengaruhi kualitas pelayanan adalah faktor aturan, dimana terdapat aturan yang bersifat mutlak agar organisasi dan pekerjaan dapat berjalan teratur dan terarah.

\section{KESIMPULAN}

Berdasarkan hasil penelitian dapat disimpulkan, kualitas pelayanan khusus perempuan dan anak yang berhadapan dengan hukum di Subdit IV Renakta Ditrekrimum Polda Kalteng Provinsi Kalimantan Tengah tahun 2020 belum optimal dari segi inovasi keterbukaan informasi eksternal seperti instagram maupun facebook dan jangka waktu penyelesaian perkara yang cukup lama. Adapaun faktor penghambat dari kualitas pelayanan ruang pelayanan khusus perempuan dan anak yang berhadapan dengan hukum di Subdit IV Renakta Ditrekrimum Polda Kalteng adalah: I) keterbukaan informasi eksternal, dimana informasi prosedur pembuatan laporan pengaduan masih belum terdapat di ruang publik seperti instagram maupun facebook yang saat ini banyak digunakan masyarakat dalam mencari informasi, 2) jangka waktu penyelesaian perkara, dimana masih ada masyarakat yang mengeluh tentang jangka waktu penyelesaian perkara yang cukup lama.
Saran dari hasil penelitian kualitas pelayanan khusus perempuan dan anak yang berhadapan dengan hukum di Subdit IV Renakta Ditrekrimum Polda Kalteng Provinsi kalimantan tengah tahun 2020.

I. Perlunya Subdit IV/Renakta Ditreskrimum Polda Kalteng melakukan inovasi terkait dengan keterbukaan informasi publik dalam pembuatan laporan dan akses penyelesaian perkara untuk mempermudah masyarakat mendapatkan informasi terkait laporan yang telah dibuat.

2. Perlunya penyampaian kepada masyarakat saat membuat laporan terkait dengan jangka waktu proses hukum atau penyelesaian perakara hingga sampai ke persidangan.

\section{UCAPAN TERIMA KASIH}

Kami sebagai peneliti mengucapkan terimakasih atas kesediaan waktu dan tempat penelitian semoga hasil penelitian ini dapat di jadikan rekomendasi perbaikan bagi mitra lembaga peneliti yang telah terjalin selama ini. semoga Allah SWT senantiasa melimpahkan rahmat, taufik, dan hidayahnya kepada kita sekalian. Amin 


\section{REFERENSI}

Arif Furchan, Pengantar Metodologi Penelitian Kualitatif, (Surabaya: Usaha Nasional, 1992)

Harbani, Pasalong. 2013. Teori Administrasi Publik. Bandung: Alfabeta. Hal. 128

Imam Gunawan, Metode Penelitian Kualitatif, Teori Dan Praktik, (Jakarta: Bumi Aksara 20I3), hlm. 80.

Imron Rosidi, Karya Tulis Ilmiah, (Surabaya: PT. Alfina Primatama, 20l I), hlm.l2.

Lexy. J. Moleong, Metodologi Penelitian Kualitatif, (Bandung: PT Remaja Rosdakarya, 2000), hlm. 135.

Moenir, A.S. 2014. Manajemen Pelayanan Umum di Indonesia. Jakarta: Bumi Aksara.

Mulyadi, D. 2015. Perilaku Organisasi dan Kepemimpinan Pelayanan. Bandung: Alfabeta. Hal 45

Mulyadi, D. 2015. Perilaku Organisasi dan Kepemimpinan Pelayanan. Bandung: Alfabeta

Mulyawan Rahman. 2016. Birokrasi dan Pelayanan Publik. Bandung : UNPAD PRESS. Hal. 14

Pelayanan Umum, openlibrary.org/b/OL// 7025260M, 2005, diakses 12 April 2017 Pukul 13:55 Wib.

Peraturan Kapolri (Perkap) Nomor 22 Tahun 2010 tentang Susunan Organisasi dan Tata Cara Kerja Polda

Peraturan Mahkamah Agung Republik Indonesia No. 3 Tahun 2017 perihal Pedoman Mengadili Perempuan Yang Berhadapan Dengan Hukum

Rahmayanty, Nina. 2010. Manajemen Pelayanan Prima. Yogyakarta: Graha Ilmu.

Sinambela, Lijan Poltak. 2014. Reformasi Pelayanan Publik, Teori Kebijakan dan Implemetasi. Jakarta: PT Bumi Aksara. Hal 7

Sugiyono, Metode Penelitian Pendidikan; Pendekatan Kuantitatif dan Kualitatif dan R\&D, Bandung: Alfabeta, 2006), hlm. 3 I0.

Sugiyono. 2015. Metode Penelitian Kombinasi (Mix Methods). Bandung: Alfabeta

Sugiyono. 2016. Metode Penelitian Kuantitatif, Kualitatif dan R\&D. Bandung. PT Alfabet

Suharsimi Ari Kunto, Managemen Penelitian, Jakarta: PT. Renika Cipta, 1993), cet. Ke-2, hlm. 309.

Suharsimi Arikunto, Prosedur Penelitian Suatu Pendekatan Praktek Edisi Revisi, Jakarta : PT. Rineka Cipta, 20I0. Hal 193
Susatyo Herlambang. 2016. Manajemen Pelayanan Kesehatan Rumah Sakit. Yogyakarta: Gosyen Publishing. Hal. I72-172

Syafri Arif, Jumadi, Abdullah. 2016. Pengembangan Model Implementasi Kebijakan Program Penanganan Anak Jalanan Untuk Pengentasan Kemiskinan di Kota Makasar. Hal. 2

Syahida, Agung, Bayu. 2014. Implementasi Perda 14 Tahun 2009 Tentang Pengelolaan Sampah di Kota Tanjung Pinang (Studi kasus di Kelurahan Tanjung Unggat). Hal. 8

Syahputra Riza. 2020. Kualitas Pelayanan Program Jaminan Kesehatan Nasional (JKN) di RSUD dr. Doris Sylvanus. UMP. Palangka Raya

Tjiptono, Fandy. 20II. Service Management Mewujudkan Layanan Prima. Edisi 2. Yogyakarta: Andi

Undang-Undang No. II Tahun 20II tentang Sistem Peradilan Pidana Anak

Undang-Undang Republik Indonesia No. 13 Tahun 2006 tentang Perlindungan Saksi dan Korban

Wahab, Solichin Abdul. 20I5. Analisis Kebijaksanaan dari Formulasi ke Penyusunan Model-Model Implementasi Kebijakan Publik. Malan: Bumi Aksara. Hal. 135

Zaitunah, Subhan. 2004. Kekerasan Terhadap Perempuan. Pustaka Pesantren: Yogyakarta. 